\title{
Valuing increased zinc (Zn) fertiliser-use in Pakistan
}

\author{
Edward J. M. Joy • Waqar Ahmad • Munir H. Zia • Diriba B. Kumssa • Scott D. Young • \\ E. Louise Ander • Michael J. Watts • Alexander J. Stein • Martin R. Broadley
}

Received: 12 February 2016 / Accepted: 13 June 2016/Published online: 8 July 2016

(C) The Author(s) 2016. This article is published with open access at Springerlink.com

\begin{abstract}
Background and aims Use of zinc (Zn) fertilisers may be cost-effective in increasing crop yields and in alleviating dietary $\mathrm{Zn}$ deficiency. However, $\mathrm{Zn}$ fertilisers are underutilised in many countries despite the widespread occurrence of Zn-deficient soils. Here, increased Zn fertiliser-use scenarios were simulated for wheat production in Punjab and Sindh Provinces, Pakistan. Inputs and outputs were valued in terms of both potential yield gains as well as health gains in the population.

Methods The current dietary $\mathrm{Zn}$ deficiency risk of $23.9 \%$ in Pakistan was based on food supply and wheat grain surveys. "Disability-adjusted life years (DALYs) lost" are a common metric of disease burden; an
\end{abstract}

Edward J. M. Joy, Waqar Ahmad, Munir H. Zia, Diriba B.

Kumssa, Martin R. Broadley Contributed equally to this paper.

Responsible Editor: Ismail Cakmak.

Electronic supplementary material The online version of this article (doi:10.1007/s11104-016-2961-7) contains supplementary material, which is available to authorized users.

\section{E. J. M. Joy}

Faculty of Epidemiology and Population Health, London School of Hygiene \& Tropical Medicine, Keppel St, London WC1E 7HT, UK

W. Ahmad

Food and Agriculture Organization of the United Nations, NARC Premises, Park Road, Islamabad, Pakistan

\section{H. Zia}

Research \& Development Section, Fauji Fertilizer Company Ltd, Rawalpindi, Pakistan estimated 245,000 DALYs ${ }^{-1}$ are lost in Punjab and $\mathrm{Sindh}$ due to $\mathrm{Zn}$ deficiency. Baseline $\mathrm{Zn}$ fertiliser-use of $7.3 \mathrm{kt} \mathrm{y}^{-1} \mathrm{ZnSO}_{4}$. $\mathrm{H} 2 \mathrm{O}$ was obtained from published and industry sources. The wheat area currently receiving $\mathrm{Zn}$ fertilisers, and grain yield responses of 8 and $14 \%$ in Punjab and Sindh, respectively, were based on a recent survey of $>2500$ farmers. Increased grain $\mathrm{Zn}$ concentrations under $\mathrm{Zn}$ fertilisation were estimated from literature data and converted to improved $\mathrm{Zn}$ intake in humans and ultimately a reduction in DALYs lost.

Results Application of $\mathrm{Zn}$ fertilisers to the area currently under wheat production in Punjab and Sindh, at current soil: foliar usage ratios, could increase dietary $\mathrm{Zn}$ supply from $\sim 12.6$ to $14.6 \mathrm{mg}$ capita $^{-1} \mathrm{~d}^{-1}$, and almost halve the

M. H. Zia • D. B. Kumssa - S. D. Young •

M. R. Broadley $(\bowtie)$

School of Biosciences, University of Nottingham, Sutton

Bonington Campus, Loughborough LE12 5RD, UK

e-mail: martin.broadley@nottingham.ac.uk

M. H. Zia • D. B. Kumssa • E. L. Ander • M. J. Watts Inorganic Geochemistry, Centre for Environmental Geochemistry, British Geological Survey, Keyworth, Nottingham NG12 5GG, UK

A. J. Stein

Agricultural Economist, Brussels, Belgium 
prevalence of $\mathrm{Zn}$ deficiency, assuming no other changes to food consumption. Gross wheat yield could increase by 2.0 and 0.6 Mt. grain $\mathrm{y}^{-1}$ in Punjab and Sindh, respectively, representing an additional return of US\$ $>800 \mathrm{M}$ and an annual increased grain supply of $19 \mathrm{~kg}$ capita $^{-1}$.

Conclusions There are potential market- and subsidybased incentives to increase $\mathrm{Zn}$ fertiliser-use in Pakistan. Benefit-Cost Ratios (BCRs) for yield alone are 13.3 and 17.5 for Punjab and Sindh, respectively. If each DALY is monetised at one to three fold Gross National Income per capita on purchasing power parity $\left(\mathrm{GNI}_{\mathrm{PPP}}\right)$, full adoption of $\mathrm{Zn}$ fertiliser for wheat provides an additional annual return of 405-1216 M International Dollars (I\$) in Punjab alone, at a cost per DALY saved of I\$ 461-619.

Keywords Agronomic biofortification - Benefit cost ratio $(\mathrm{BCR}) \cdot$ Cost-benefit analysis · Disability adjusted life year (DALY) · Fertiliser subsidy · Food security .

Triticum aestivum $\mathrm{L}$. Wheat

\section{Introduction}

Zinc ( $\mathrm{Zn})$ is an essential nutrient for all organisms, with potential roles in 1000s of proteins in plants and humans (Broadley et al. 2007). Crops respond to $\mathrm{Zn}$ fertilisers on many soil types. For example, increases in wheat yield and production at a national scale have been reported in Turkey following the adoption of $\mathrm{Zn}$ fertilisers (Cakmak 2008; Cakmak et al. 2010). However, Zn fertilisers remain little utilised globally, and approximately half of all soils used for cereal production are likely to be $\mathrm{Zn}$ deficient (Cakmak et al. 1999; Alloway 2008; Ahmad et al. 2012). These soils include widespread areas of the Indo-Gangetic Plains in South Asia, where intensive rice-wheat cropping systems are practiced (e.g. Nayyar et al. 2001). For example, soils of the Indus Plains of Pakistan are mostly derived from calcareous parent material from the Himalayas, which is deposited as alluvial material by the Indus River and its tributaries, or as loess deposits in the northern parts of the Indus Plains (FAO 1973). These calcareous soils support the majority of crop production in Pakistan, which covers 21.4 Mha (PBS 2009). These soils generally have low organic matter $(0.4-0.7 \%)$ and free calcium carbonate $\left(\mathrm{CaCO}_{3}\right)$, which buffers the $\mathrm{pH}$ within the range of 7.5-8.4 with $100 \%$ base saturation, and have a cation exchange capacity (CEC) dominated by $\mathrm{Ca}$. These factors tend to restrict the phyto-availability of $\mathrm{Zn}$ and other elements such as boron (B), thereby limiting crop yields in the absence of their fertilisers.

Many field studies have reported crop yield increases in response to $\mathrm{Zn}$ fertilisers. Using these studies, it is straightforward to monetise Benefit-Cost-Ratios (BCRs) based on increased crop output per additional input of $\mathrm{Zn}$. For example, in a review of field studies in Pakistan, an application of $5 \mathrm{~kg} \mathrm{ha}^{-1}$ (i.e. $\mathrm{ZnSO}_{4}$. $\mathrm{H} 2 \mathrm{O}$ equivalents, containing $\sim 33 \% \mathrm{Zn}$ ) increased grain yields of wheat by $>10 \%$, at a mean BCR of 7:1 (range 1.3-11:1; NFDC 1998). In addition to yield increases in the year of $\mathrm{Zn}$ fertiliser application, there may be beneficial residual effects of $\mathrm{Zn}$ fertilisers for subsequent crops for three or more years (NFDC 1998; Singh and Shivay 2013; Manzeke et al. 2014; Wang et al. 2015a). However, despite these potential financial returns, $\mathrm{Zn}$ fertilisers remain little utilised in Pakistan and elsewhere, for several reasons. These include a lack of quality product availability/access and farmer-awareness. There is also evidence of an unwillingness to pay for $\mathrm{Zn}$ fertilisers due to mistrust of product quality and labelling (NFDC 1998). The effects of subsidies that focus primarily on the supply of macronutrient fertilisers, and a lack of farmeraccess to longer-term credit, can also discourage longerterm soil fertility-building and lead to imbalanced fertiliser-use at a farm level (Khan et al. 2010). Furthermore, there are scientific knowledge gaps in terms of deploying balanced fertiliser applications in soils with multiple macro- and micro-nutrient stresses including Bdeficiency and saline/sodic soil systems, which are prevalent in Pakistan (Ahmad and Muhammad 1998).

The use of $\mathrm{Zn}$ fertilisers can also increase $\mathrm{Zn}$ concentration in the endosperm of cereal-grains, thereby reducing risks to consumers of dietary $\mathrm{Zn}$ deficiency (Cakmak 2009; White and Broadley 2009, 2011; Cakmak et al. 2010; Joy et al. 2015b). The impact of increased dietary $\mathrm{Zn}$ intake and subsequent reductions in $\mathrm{Zn}$ deficiency within populations can be quantified using a Disability-adjusted life years (DALYs) framework (Murray 1994; Stein et al. 2005, 2006; Stein 2014). The use of DALYs allows health losses due to morbidity, injury and mortality to be expressed in a single metric. This measure can then also be used to quantify the impact of public health interventions in terms of "DALYs saved" and to rank potential interventions by taking their underlying costs into account. In this case the key metric is the "cost per DALY saved" for each intervention with a lower cost per DALY representing a more cost-effective intervention. 
For example, Joy et al. (2015b) estimated that foliar Zn application to $75 \%$ of cereals in 10 countries in subSaharan Africa could increase $\mathrm{Zn}$ intakes by $\sim 1.0 \mathrm{mg} \mathrm{Zn}$ capita $^{-1} \mathrm{~d}^{-1}$, saving $0.5 \mathrm{M}$ DALYs annually at a cost of US\$ 46-347 per DALY saved. In comparison, Stein et al. (2006) estimated that biofortification of high-Zn rice and wheat varieties through breeding could save up to $55 \%$ of the 2.8 M DALYs lost annually due to Zn deficiency in India at a cost of US\$ $0.68-8.80$ per DALY saved. Fiedler et al. (2013) estimated that fortifying maize meal with a premix containing $\mathrm{Zn}$ at large-scale mills in Zambia could save 5657 DALYs annually, of which 1757 were due to $\mathrm{Zn}$ deficiency, at a cost of US\$ 401 per DALY saved. While the cost-effectiveness of these interventions varies considerably, it is also necessary to take into account the socioeconomic realities in each target country. The Commission on Macroeconomics and Health of the World Health Organization (WHO 2001) suggested valuing each DALY lost at the national per capita income (or even at three times the per capita income). Under this criterion the above (bio) fortification interventions are likely to be worth implementing in their respective settings.

The aim of this study was to compare the potential financial return from $\mathrm{Zn}$ fertilisers, both in terms of yield and public health, using yield BCRs and DALYs. Combining yield and health-based valuations of an increased supply of micronutrients that is delivered through fertilisers has not previously been attempted to our knowledge. Pakistan was chosen as a case study because: (1) of a high prevalence of $\mathrm{Zn}$ deficient soils and human dietary $\mathrm{Zn}$ deficiency; (2) a large proportion of dietary energy intake is from wheat; (3) of good data availability on fertiliser-use from public and private sector sources, notably the National Fertilizer Development Centre (NFDC). The NFDC was set up by the Government of Pakistan in 1977, with support from United Nations Development Programme (UNDP), the Food and Agriculture Organization (FAO) of the UN, the Governments of Norway, the Netherlands and other international donors (http://www.nfdc.gov.pk/about.html). The NFDC compile fertiliser-use statistics at a districtlevel scale that are used for policy support and to guide $\mathrm{R} \& \mathrm{D}$ and communication priorities.

\section{Methods}

Baseline assumptions for yield and health-based valuations were made using recent data from Pakistan for: (1) dietary $\mathrm{Zn}$ supply from wheat, grown with and without $\mathrm{Zn}$ fertilisers; (2) current $\mathrm{Zn}$ fertiliser practices and costs; (3) wheat production statistics and support prices; (4) estimated disease burden in terms of lost DALYs due to $\mathrm{Zn}$ deficiency. Data were obtained from published and unpublished sources, including a large-scale survey of farmer practices in Punjab and Sindh. The value of increasing $\mathrm{Zn}$ fertiliser-use from this baseline was estimated using scenario changes combined with explicit assumptions described below. The study focuses on Punjab and Sindh as the major agricultural production regions of Pakistan and because of data availability. The study focuses on wheat as the dominant dietary source of energy and $\mathrm{Zn}$ in Pakistan (FAO 2015).

Dietary $\mathrm{Zn}$ supply from wheat under baseline and $\mathrm{Zn}$-fertilised scenarios

Recent published estimates of dietary energy supply from wheat, rice and other main food sources were obtained from Kumssa et al. (2015b). The supply of $\mathrm{Zn}$ for Pakistan was estimated to be $13.9 \mathrm{mg} \mathrm{Zn}$ capita $^{-1}$ $\mathrm{d}^{-1}$ in 2010 (Kumssa et al. 2015b; Fig. 1). This is based on FAO Food Balance Sheets for 2010 (FAO 2015), which report a supply of $311 \mathrm{~g}_{\text {capita }}^{-1} \mathrm{~d}^{-1}$ of wheat grain and USDA food composition data of $29.1 \mathrm{mg} \mathrm{Zn}$ $\mathrm{kg}^{-1}$ (USDA 2013). Wheat would therefore supply $8.3 \mathrm{mg} \mathrm{Zn}$ capita $^{-1} \mathrm{~d}^{-1}$ after correcting for edible portion (Supplementary Table 1). Wheat is the major staple food in Pakistan, contributing $37 \%$ of the daily energy in the Pakistan food supply system. The supply of rice is

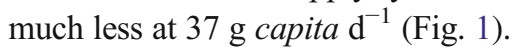

USDA data is likely to overestimate the $\mathrm{Zn}$ concentration of wheat grain grown on soils with low-Zn availability such as in Pakistan. Thus, we adjusted estimates of dietary Zn supply, using data from grain samples of wheat grown in Pakistan on soils of contrasting $\mathrm{Zn}$ status. Collection of these grain samples was described previously (Zia et al. 2015). The mean/median grain $\mathrm{Zn}$ concentration was 24.9/24.5 $\mathrm{mg} \mathrm{kg}^{-1}$ (standard deviation $=4.8$; range $=15.1-39.7, n=75 ;$ Munir H. Zia and Michael J. Watts, unpublished observations). Using a mean grain $\mathrm{Zn}$ concentration value of $24.9 \mathrm{mg} \mathrm{kg}^{-1}$ represents a supply of $7.1 \mathrm{mg} \mathrm{Zn} \mathrm{capita}{ }^{-1} \mathrm{~d}^{-1}$ from wheat for Pakistan in 2010, after correcting for edible portion, and a baseline dietary $\mathrm{Zn}$ deficiency risk of $23.9 \%$ compared to $16.1 \%$ based on USDA wheat composition data. Both estimates assume a national population-weighted Estimated Average Requirement 


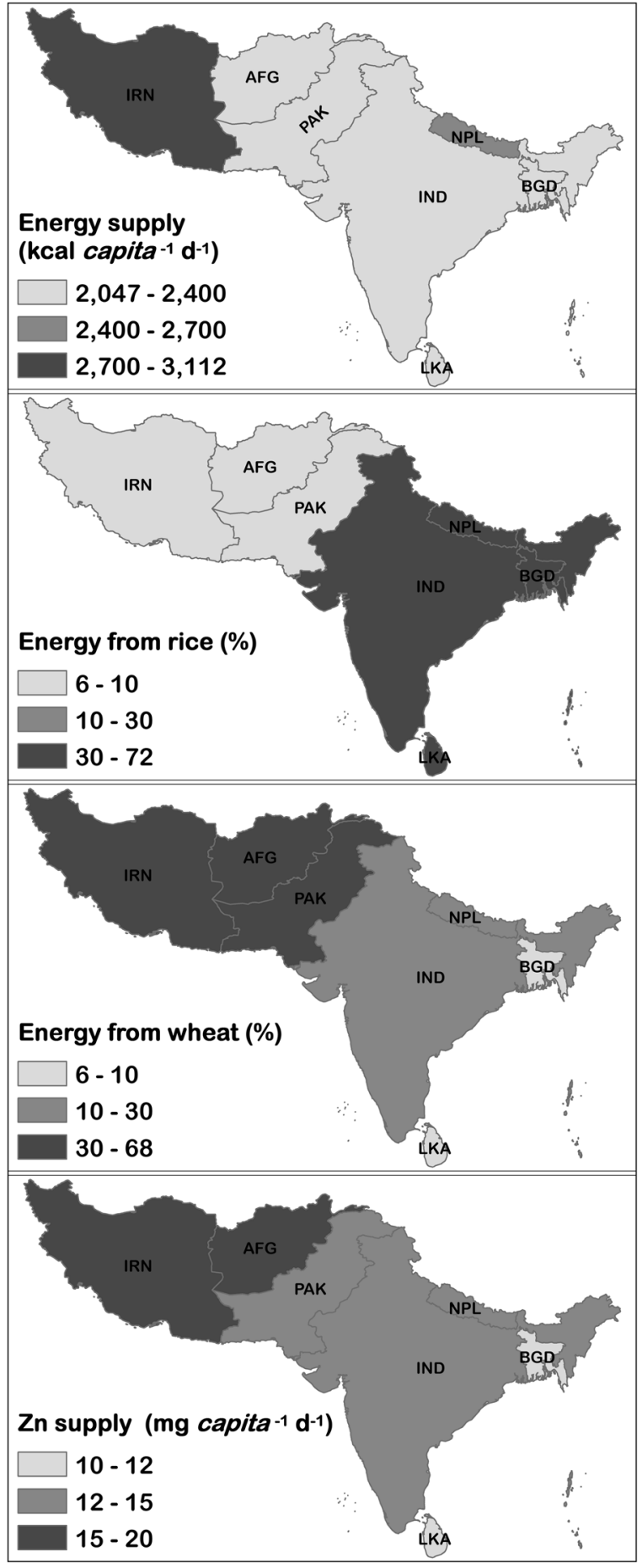

Fig. 1 Dietary energy supply in 2010 for S. Asia, a from all foods; b from rice; c from wheat. d dietary $\mathrm{Zn}$ supply. Data are from Kumssa et al. (2015b)

(EAR) of $10.4 \mathrm{mg} \mathrm{Zn}$ capita $^{-1} \mathrm{~d}^{-1}$ (Kumssa et al. 2015b). These baseline estimates of dietary Zn deficiency are likely to underestimate the extent of nutritional $\mathrm{Zn}$ deficiency. For example, the 2011 Pakistan National Nutrition Survey Report (NNS 2011) reported that $42 \%(n=5953)$ and $48 \%(n=791)$ of non-pregnant and pregnant women respectively and $37 \%(n=2499)$ of children $<5$ years were $\mathrm{Zn}$-deficient, based on having plasma $\mathrm{Zn}$ concentrations $<60 \mu \mathrm{g} \mathrm{Zn} \mathrm{dL}{ }^{-1}$. This discrepancy is likely to be due to: (1) an over-estimate of dietary $\mathrm{Zn}$ supply, considering the use of USDA food composition data for food items other than wheat and considering that food supply data does not account for household-level wastage; (2) the assumption of a $25 \%$ coefficient of variation in dietary $\mathrm{Zn}$ intakes may underestimate the inequality of access to food due to socio-economic or social exclusion factors (Joy et al. 2014, 2015a, b; Kumssa et al. 2015a, b; Kuper et al. 2015); and (3) nutritional Zn deficiency can occur despite adequate dietary $\mathrm{Zn}$ supply due to factors such as diarrhoeal disease.

\section{Zn fertiliser practices and costs}

Fertiliser-use is currently unbalanced in Pakistan. In 2012/13, total fertiliser availability was 3865 kilotonnes (kt; NFDC 2013). This comprised $2975 \mathrm{kt}$ of N, $863 \mathrm{kt}$ of phosphate $\left(\mathrm{P}_{2} \mathrm{O}_{5}\right)$, and $27 \mathrm{kt}$ of potash $\left(\mathrm{K}_{2} \mathrm{O}\right)$. The offtake (consumption, nutrient weight) of fertilizer during this period was $3621 \mathrm{kt}$, comprising $2853 \mathrm{kt} \mathrm{N}, 747$ $\mathrm{kt}$ phosphate, and $21 \mathrm{kt}$ potash. The difference between availability and offtake is the amount carried forward into the next fiscal year, i.e. $2013 / 14$. Urea $\left(\mathrm{CO}\left(\mathrm{NH}_{2}\right)_{2}\right.$; 46:0:0 NPK) comprised $84 \%$ of total $\mathrm{N}$ fertilisers used in 2012/13 (NFDC 2013). In terms of nutrient weights, $2391 \mathrm{kt}$ of $\mathrm{N}$ use was from urea, $112 \mathrm{kt}$ was from calcium ammonium nitrate (CAN; $\left.5 \mathrm{Ca}\left(\mathrm{NO}_{3}\right)_{2} \cdot \mathrm{NH}_{4} \mathrm{NO}_{3} \cdot 10 \mathrm{H}_{2} \mathrm{O} ; \sim 26: 0: 0\right), 242 \mathrm{kt}$ was from diammonium phosphate (DAP; $\left.\left(\mathrm{NH}_{4}\right)_{2} \mathrm{HPO}_{4} ; 18: 46: 0\right)$, $103 \mathrm{kt}$ was from nitrophos (NP; 22:20:0), with much smaller amounts of $\mathrm{N}$ from NPK fertilisers of varying composition and $<1 \mathrm{kt}$ from monoammonium phosphate (MAP; $\mathrm{NH}_{4} \mathrm{H}_{2} \mathrm{PO}_{4} ; 11: 52: 0$ ). The most widely used form of phosphate in Pakistan is DAP (NFDC 2013). In 2012/13, this comprised $83 \%$ of total phosphate fertiliser-use. In terms of $\mathrm{P}_{2} \mathrm{O}_{5}$ nutrient weight, $619 \mathrm{kt}$ of phosphate use was from DAP, with $103 \mathrm{kt}$ from NP, and $16 \mathrm{kt}$ from single superphosphate (SSP; $\left.\mathrm{Ca}\left(\mathrm{H}_{2} \mathrm{PO}_{4}\right)_{2} ; 0: 14-18: 0\right)$. There is negligible use of phosphate from triple superphosphate (TSP; $\mathrm{Ca}\left(\mathrm{H}_{2} \mathrm{PO}_{4}\right)_{2}$. H2O; 0:46:0) or NPK sources. Similarly, there is minimal potash fertiliser usage of just $21 \mathrm{kt}$ in 
2012/13 (NFDC 2013). This included $8 \mathrm{kt}$ of sulphate of potash ( $\mathrm{SOP} ; \mathrm{K}_{2} \mathrm{SO}_{4} ; \sim 0: 0: 50$ ), $3.6 \mathrm{kt}$ of muriate of potash (MOP; $\mathrm{KCl} ; \sim 0: 0: 60$ ), and the rest as NPK fertilisers.

Data for micronutrient fertiliser-use in Pakistan are not widely available, although usage is undoubtedly low. Baseline Zn fertiliser-use data for the 2012/13 cropping season were obtained from NFDC (2013), however, these include data solely for Engro Fertilizer Ltd. (Fig. 2a, b; NFDC, 2013). Data from Fauji Fertilizer Company Ltd. are from 2014 (Fig. 2c, d; Munir H. Zia, unpublished data, Fauji Fertilizer Company Ltd., FFC, Rawalpindi). Other major companies such as Fatima Fertilizer Company have recently started selling $\mathrm{Zn}$ fertilisers but sales data are not yet available. Fauji and Engro are likely to represent $>50 \%$ of the current $\mathrm{Zn}$ fertiliser market in Pakistan. It can be concluded from these data sources that the current use of $\mathrm{Zn}$ fertilisers in Pakistan is low (Fig. 2). Estimated annual use of $\mathrm{Zn}$ products on wheat is $7300 \mathrm{t}$ (i.e. $\mathrm{ZnSO}_{4}$. $\mathrm{H} 2 \mathrm{O}$ equivalents, $33 \% \mathrm{Zn}$ ). Product use comprises $5100 \mathrm{t} \mathrm{ZnSO}_{4}$. $\mathrm{H} 2 \mathrm{O}$ which are applied to soils in granular or powder forms, and $10,700 \mathrm{t}$ of liquid $\mathrm{Zn}$, including both $\mathrm{ZnSO}_{4} \cdot \mathrm{H}_{2} \mathrm{O}$ and chelated $\mathrm{Zn}$ forms which is equivalent to $2200 \mathrm{t}$ of granular $\mathrm{ZnSO}_{4}$. $\mathrm{H} 2 \mathrm{O}$.
This represents a granular:foliar $\mathrm{Zn}$-use ratio of $\sim 0.7: 0.3$. Zinc fertiliser-use, i.e. usage divided by area under wheat production, is therefore $<<1 \mathrm{~kg} \mathrm{ha}^{-1}$ for most districts in Pakistan. Input costs for $\mathrm{Zn}$ were assumed to be US\$ $1600 \mathrm{t}^{-1} \mathrm{ZnSO}_{4} \cdot \mathrm{H}_{2} \mathrm{O}$ (2015 value; Munir H. Zia, personal communication). This amount is the approximate amount paid by the farmer, which comprises the cost of the raw product received at the port ( $\sim 50 \%$ of the cost in 2015), plus other costs including product unloading, transport, packaging, administration, and profit margin. Zinc fertilisers are used most widely in Punjab and Sindh, with limited use elsewhere in Pakistan (Fig. 2).

Baseline data for on-farm Zn fertiliser-use were obtained for Punjab and Sindh from a survey of $>2500$ farmers taken in early 2015 (Waqar Ahmad, personal communication, Food and Agriculture Organization of the United Nations, FAO, Islamabad). As part of a broader study, farmers were asked to recall information including farm-size, major crop types and yields from the 2014 harvest (i.e. wheat, rice, cotton, sugarcane, maize, other). They were also asked to recall cropspecific fertiliser usage, in terms of urea and CAN use for N; DAP/MAP/SSP/NP use for P; MOP/SOP use for $\mathrm{K} ; \mathrm{Zn}$ and $\mathrm{B}$ use). In this way, data were obtained from
Fig. 2 Zinc fertiliser use in Pakistan by District. a, b, data for Engro Fertilizer Ltd. for 2012/13 (NFDC 2013). c, d, unpublished data of Fauji Fertilizer Company Ltd., Rawalpindi, Pakistan (2014 calendar year). Units are tonnes of $\mathrm{ZnSO} 4 . \mathrm{H}_{2} \mathrm{O}$ equivalents $(\mathbf{a}, \mathbf{c})$ and $\mathrm{kg} \mathrm{ha}-{ }^{1}$ based on wheat production area as a proxy for suitable land (b, d). Pakistan's district shape files are from Global Administrative Areas (GADM) database (http://www. gadm.org/). Data represent $>50 \%$ of $\mathrm{Zn}$ market

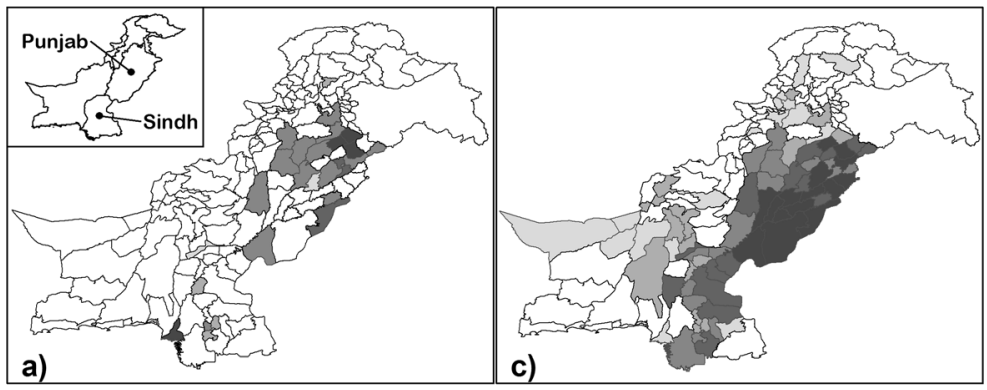

$\mathrm{ZnSO}_{4} \cdot \mathrm{H}_{2} \mathrm{O}$ offtake (tonnes district ${ }^{-1}$ )

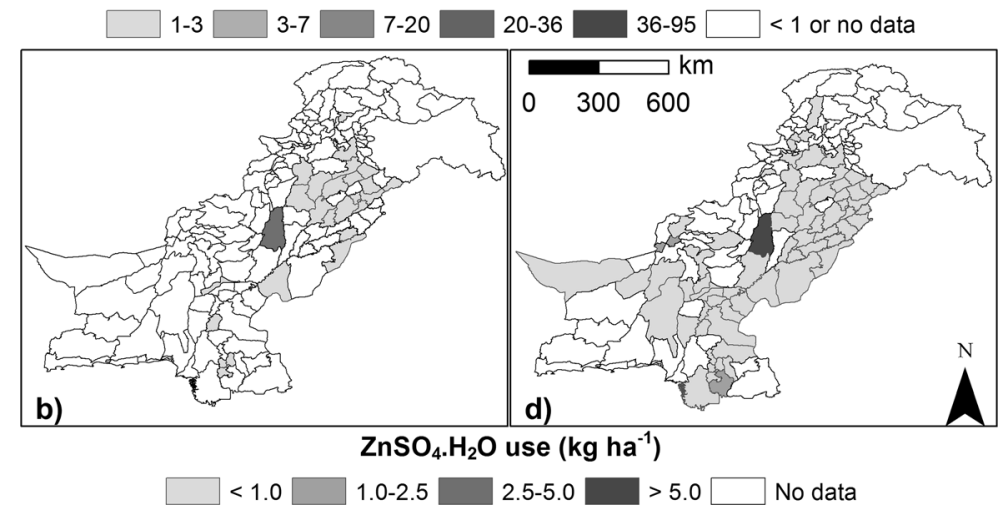


1193 and 1338 farmers in Punjab and Sindh Provinces, respectively. There were consistent positive relationships between $\mathrm{N}$ and $\mathrm{P}_{2} \mathrm{O}_{5}$ application rates and wheat yield (Fig. 3), confirming that these survey data are a useful proxy for this current study. For example, wheat yields increased from $\sim 2 \mathrm{tha}^{-1}$ at the lowest $\mathrm{N}$ application rates, to 4.4 and $3.9 \mathrm{t} \mathrm{ha}^{-1}$ at an application rate of $92 \mathrm{~kg} \mathrm{~N} \mathrm{ha}{ }^{-1}$.

In Punjab and Sindh, 14.4 and $23.2 \%$ of farmers, respectively, reported using $\mathrm{Zn}$ fertilisers on wheat. This corresponds to a total area receiving $\mathrm{Zn}$ fertiliser of 1.1 and 0.4 Mha in Punjab and Sindh, respectively. Among farmers reporting $\mathrm{Zn}$ fertiliser-use, the mean application rate was $4.8 \mathrm{~kg} \mathrm{ZnSO} \cdot \mathrm{H}_{2} \mathrm{O}$ ha ${ }^{-1}$, based on dividing this area by $7.3 \mathrm{kt}$. The mean wheat yield without $\mathrm{Zn}$ fertilisers was 4.0 and $3.1 \mathrm{t} \mathrm{ha}^{-1}$ in Punjab and Sindh Provinces, respectively (Fig. 4).

Wheat production data and support prices

Area under wheat production was derived from the Pakistan Agriculture Census, with 7.5 and 1.9 $\mathrm{M}$ ha in Punjab and Sindh provinces, respectively (PBS 2010; Table 1). The mean yield is 2.5 and $1.9 \mathrm{t} \mathrm{ha}^{-1}$ in Punjab and Sindh, respectively (PBS 2009), of which $90 \%$ and $97 \%$ is irrigated (PBS 2010). Output prices of wheat are based on a support price of US\$ $312 \mathrm{t}^{-1}$ (October 2015 value; Munir H. Zia, personal communication).
Disease burden due to Zn deficiency

An estimated 323,214 DALYs were lost due to $\mathrm{Zn}$ deficiency in Pakistan in 2010 on the basis of dietary $\mathrm{Zn}$ deficiencies, the prevalence of stunting, and a total population of $182 \mathrm{M}$ (Wessells and Brown 2012; Lim et al. 2012; IHME 2014; UNDP 2013). This is equivalent to 187 DALYs lost $100 \mathrm{k}^{-1}$ population. Recent population data for Punjab and Sindh are not available in the public domain, however these provinces comprised $54 \%$ and $22 \%$ of national population in 1998 (PCO 1998) so their 2010 populations were estimated to be $92.9 \mathrm{M}$ and $38.4 \mathrm{M}$, respectively. Thus, in 2010, 173,506 and 71,746 DALYs were lost pro rata per annum in Punjab and Sindh, respectively. As dietary $\mathrm{Zn}$ supplies increase, we assume that DALYs lost due to $\mathrm{Zn}$ deficiency will decrease at the same rate as the national prevalence of $\mathrm{Zn}$ deficiency from a baseline of $24.3 \%$ and $22.8 \%$ in Punjab and Sindh, respectively, and assuming no additional food consumption (Supplementary Tables 3, 4).

Assumptions used to simulate increased $\mathrm{Zn}$ fertiliser-use

To estimate the value of potential increased $\mathrm{Zn}$ fertiliser usage, an instantaneous, area-based approach was adopted, with no time dimension or discounting factors. This is justified because $\mathrm{Zn}$ fertilisers could be deployed immediately by incorporating $\mathrm{Zn}$ with existing granular $\mathrm{N}$ fertilisers or pesticide/fungicide sprays. We assumed that
Fig. 3 Yield-responses of wheat to $\mathrm{N}$ (urea) and $\mathrm{P}_{2} \mathrm{O}_{5}$ (diammonium phosphate, DAP) applications. Data are from 1193 and 1338 farmers in Punjab and Sindh Provinces, respectively, from a survey conducted in early 2015 from 2014 harvest data (Waqar Ahmad, personal communication, Food and Agriculture Organization of the United Nations, FAO, Islamabad)

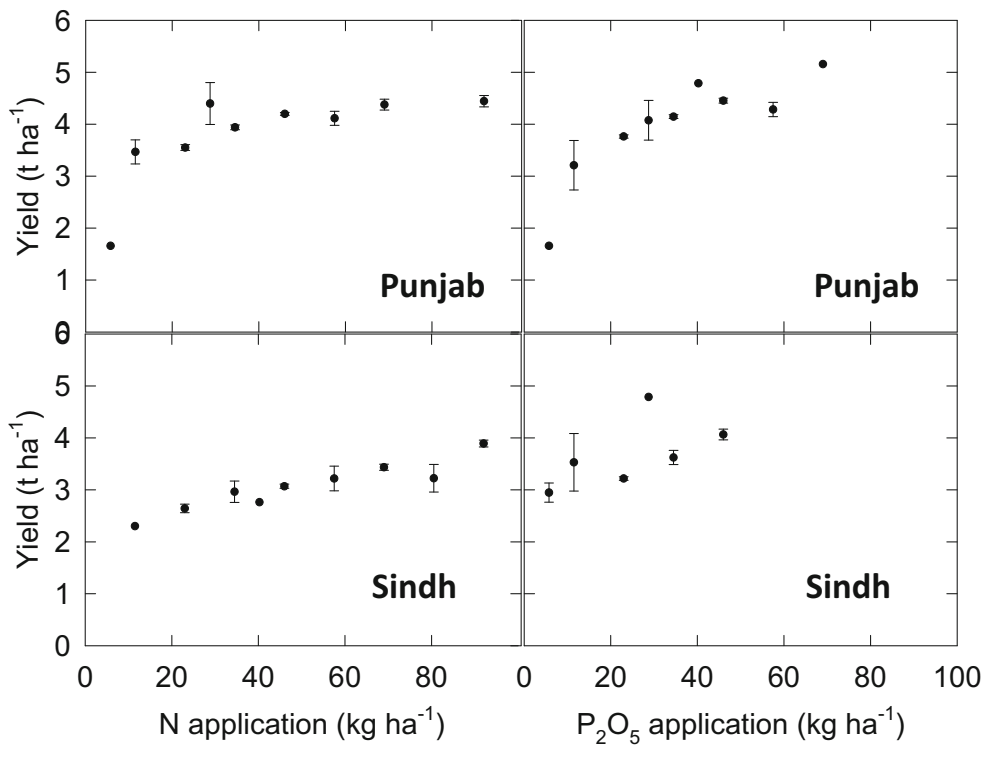




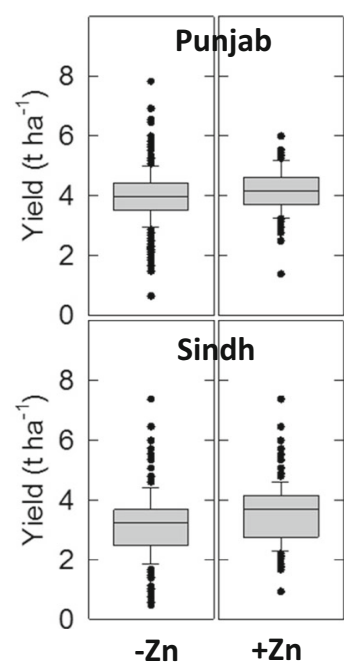

Fig. 4 Yield-response of wheat to $\mathrm{Zn}$ applications. Data are from 1193 and 1338 farmers in Punjab and Sindh Provinces, respectively, from a survey conducted in early 2015 from 2014 harvest data (Waqar Ahmad, personal communication, Food and Agriculture Organization of the United Nations, FAO, Islamabad). In Punjab, 1021 and 172 farmers reported zero-Zn $(-\mathrm{Zn})$ and $\mathrm{Zn}$ fertiliser use $(+\mathrm{Zn})$, respectively. In Sindh, the equivalent figures were 1028 and 310 . Boxes represent the middle two quartiles; whiskers represent the $95 \%$ confidence limits; outliers circled. Median increases are indicated by the horizontal line within the box. Yield increases in both Punjab and Sindh were significant $(P<0.001)$

the proportion of wheat fertilised at $4.8 \mathrm{~kg} \mathrm{ha}^{-1}$ could incrementally increase from the current 14.4 and $23.2 \%$ of the areas currently under wheat production in Punjab and Sindh, respectively, up to $100 \%$ of these areas. The granular:foliar $\mathrm{Zn}$ fertiliser-use ratio of $\sim 0.7: 0.3$, based on current industry estimates, was assumed to remain constant.

Grain yields were assumed to increase by $8 \%$ and $14 \%$ under Zn fertilisation in Punjab and Sindh, respectively, according to median data from the farmer survey (Fig. 4). These increases were both highly significant (Student's t-tests; $P<0.001$ ). This represents an areanormalised potential yield increase of $9 \%$ for Punjab and Sindh combined. These survey data are therefore consistent with median yield increases of $16 \%$

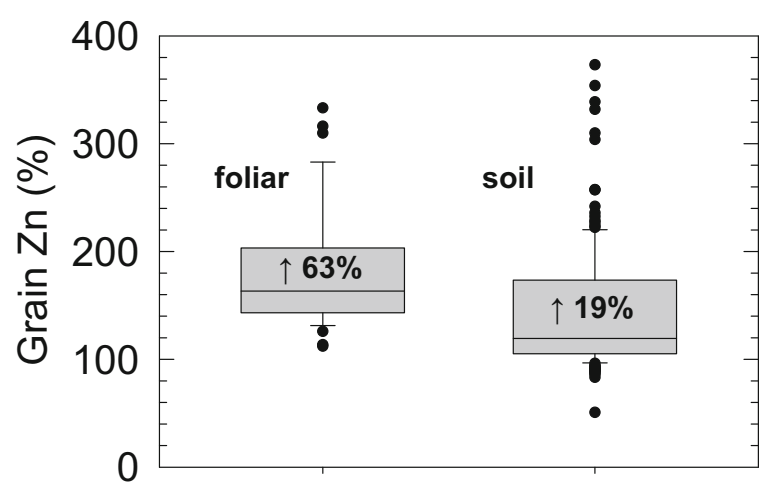

Fig. 5 Increases in wheat grain $\mathrm{Zn}$ concentration as a result of foliar- or soil-applied/granular $\mathrm{Zn}$ fertilisers compared to unfertilised controls. Boxes represent the middle two quartiles; whiskers represent the $95 \%$ confidence limits; outliers circled. Median increases are indicated by the horizontal line and text within the box. Data are from a literature-survey of Joy et al. (2015b)

following soil $\mathrm{Zn}$ application in six site-years in Pakistan (Zou et al. 2012) and 10-11\% from applications of $\mathrm{Zn}$ fertilisers to maize, rice and wheat in a recent global literature review (Joy et al. 2015b). The potential increases in grain $\mathrm{Zn}$ concentration in wheat resulting from granular and foliar $\mathrm{Zn}$ fertiliser-use were taken from this same review. From 15 studies of wheat, comprising 196 combinations of location, cultivar and application rate, granular (soil-applied) and foliar $\mathrm{Zn}$ fertilisers resulted in median increases in grain $\mathrm{Zn}$ concentration of $19 \%$ and $63 \%$, respectively (Fig. 5; Joy et al. 2015b). We therefore assumed that granular fertilisers increased grain $\mathrm{Zn}$ concentration by $19 \%$, from a baseline of $23.6 \mathrm{mg} \mathrm{kg}^{-1}$ (i.e. the $24.9 \mathrm{mg} \mathrm{kg}^{-1}$ was adjusted to assume zero $\mathrm{Zn}$ fertilisation) to $28.1 \mathrm{mg} \mathrm{kg}^{-1}$, and that foliar fertilisers increased grain $\mathrm{Zn}$ concentration by $63 \%$ to $38.5 \mathrm{mg} \mathrm{kg}^{-1}$. Thus, the weighted mean increase in grain $\mathrm{Zn}$ concentration under $\mathrm{Zn}$ fertilisation was assumed to be $32.2 \%$, giving a concentration of $\mathrm{Zn}$-fertilised wheat grain of $31.2 \mathrm{mg} \mathrm{kg}^{-1}$. All calculations are presented in Supplementary Tables 2-4.

Table 1 Wheat yields and production for Punjab and Sindh Provinces, Pakistan. Data from Pakistan Bureau of Statistics (2010), which reports that 90 and $97 \%$ of wheat is irrigated in Punjab and Sindh, respectively

\begin{tabular}{llllcl}
\hline & $\begin{array}{l}\text { Total area cropped } \\
\text { (Mha) }\end{array}$ & $\begin{array}{l}\text { Proportion of cropped } \\
\text { area in wheat (\%) }\end{array}$ & $\begin{array}{l}\text { Cropped area of wheat } \\
\text { (Mha) }\end{array}$ & Wheat production (Mt) & $\begin{array}{l}\text { Wheat mean yield } \\
\left(\mathrm{t} \mathrm{ha-}{ }^{1}\right)\end{array}$ \\
\hline Punjab & 18.2 & 41 & 7.5 & 18.4 & 2.5 \\
Sindh & 5.0 & 38 & 1.9 & 3.5 & 1.9 \\
Pakistan & 27.5 & $\sim 37$ & $\sim 10$ & $\sim 25$ & $\sim 2.7$ \\
\hline
\end{tabular}


The value of one DALY was monetised using multiples of Gross National Income (GNI) per capita, converted to International Dollars (I\$) based on purchasing power parity $\left(\mathrm{GNI}_{\mathrm{PPP}}\right)$. An $\mathrm{I} \$$ has the equivalent purchasing power as a US\$ dollar in the US based on the 2011 International Comparison Program. A per capita GNI $_{\text {PPP }}$ in Pakistan of I\$ 5110 (http://data.worldbank. org/indicator/NY.GNP.PCAP.PP.CD) was used based on data in October 2015.

\section{Results}

Potential increases in dietary $\mathrm{Zn}$ supply with increased $\mathrm{Zn}$ fertiliser-use

If all wheat was fertilised with $\mathrm{Zn}$, we project that dietary $\mathrm{Zn}$ supply would increase from 12.6 and $12.8 \mathrm{mg}_{\text {capita }}{ }^{-1} \mathrm{~d}^{-1}$ in Punjab and Sindh, respectively, to $14.5 \mathrm{mg}$ capita $^{-1} \mathrm{~d}^{-1}$ (Fig. 6a, b). Zinc deficiency prevalence would decrease from 24.8 and $23.1 \%$, to 12.9 and $12.7 \%$, in Punjab and Sindh, respectively.

Potential increases in wheat production with increased Zn fertiliser-use

A projected increase in wheat yield in Punjab from 4.0 to $4.3 \mathrm{t} \mathrm{ha}^{-1}$ would translate to an overall increase in production from 29.9 to $32.0 \mathrm{Mt} \mathrm{y}^{-1}$ (Fig. 6c) if the entire current area under wheat production was fertilised with $\mathrm{Zn}$. This represents a potential increase in the monetary value of Punjab's wheat harvest from US\$ $9300 \mathrm{M}$ to US\$10,000 M (Fig. 6e). Expenditure on Zn fertilisers would increase by US\$ $49 \mathrm{M}$, at a BCR of 13.3 (Fig. 6g). An increase in wheat yield in Sindh from 3.2 to $3.6 \mathrm{t} \mathrm{ha}^{-1}$ would translate to an overall increase in production from 6.1 to $6.7 \mathrm{Mt} \mathrm{y}^{-1}$ (Fig. 6d). This represents a potential monetary increase in the value of
Fig. 6 Projected responses to increasing $\mathrm{Zn}$ fertiliser use in Punjab (a, c, e, g) and Sindh (b, d, f, h) Provinces, Pakistan. (a, b) Dietary $\mathrm{Zn}$ supply from all food sources; (c, d) total wheat yield. $(\mathbf{e}, \mathbf{f})$ Gross financial return in which yield (solid line) is expressed in current US Dollars (US\$) and health benefits are expressed in International Dollars (I\$) in which the value of a Disability Adjusted Life Year (DALY) is expressed as a 1 (dotted line), 2 (short-dashed line) or 3 (long-dashed line) multiples of Gross National Income based on parity purchasing power (GNIPPP) which is US\$ 5110 for Pakistan from the 2011 International Comparison Program. (g, h) Benefit-Cost-Ratios for $\mathrm{Zn}$ use on wheat based on the ratio of return per unit input cost; lines labelled as described previously

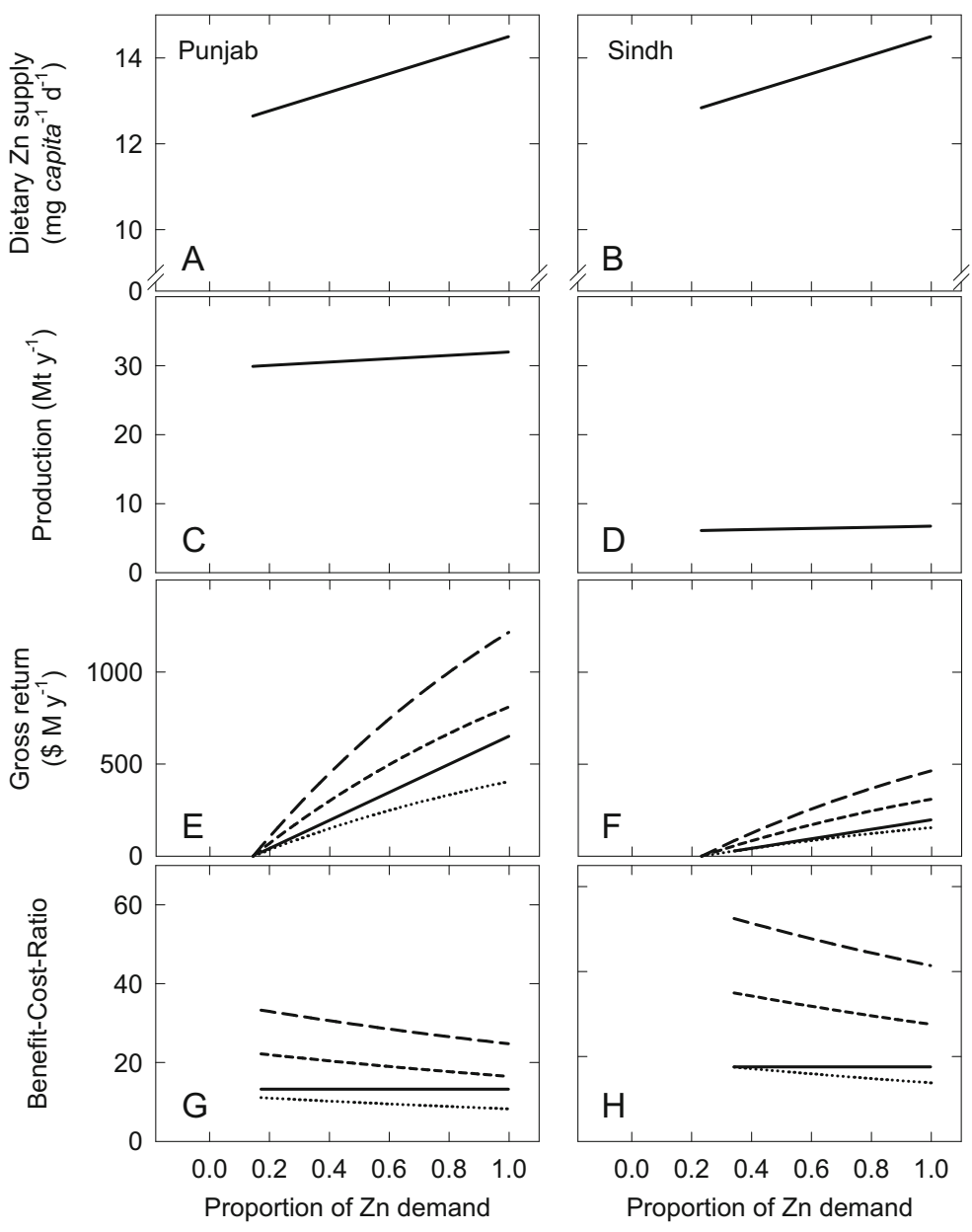


Sindh's wheat harvest from US\$ $1900 \mathrm{M}$ to US\$ 2100 M (Fig. 6f). Expenditure on Zn fertilisers would increase by US\$ $11.2 \mathrm{M}$, which equates to a BCR of 17.5 (Fig. 6h). These BCRs are based on 2015 prices of US\$ $1600 \mathrm{t}^{-1}$ for $\mathrm{ZnSO}_{4} \cdot \mathrm{H}_{2} \mathrm{O}$ and a wheat support price of US\$ $312 \mathrm{t}^{-1}$. These BCRs are greater than those reported previously, which ranged from 1.3:1 to 11:1, with a mean of 7:1 (NFDC 1998). However, at the end of 1997 , the price to farmers of $\mathrm{ZnSO}_{4} \cdot \mathrm{H}_{2} \mathrm{O}$ was US\$ $2378 \mathrm{t}^{-1}$ and the wheat support price was US\$ $136 \mathrm{t}^{-1}$ (Munir H. Zia, personal communication). Our current BCR estimates are therefore expected to be $>3$-fold greater than for estimates based on the equivalent inputs and yields in 1997, and our data are therefore consistent with previous studies in the region (NFDC 1998). It is important to note that our baseline estimates of wheat production for each province are extrapolated from grain yields reported in the farmer survey, which are greater than actual yield averages for Pakistan. Thus, our baseline estimates of wheat production exceed actual current wheat production.

\section{Decreases in DALYs lost}

Given the projected increase in dietary $\mathrm{Zn}$ supply, the number of DALYs lost annually due to $\mathrm{Zn}$ deficiency would decrease from $174 \mathrm{k}$ to $94 \mathrm{k}$ in Punjab, and from $72 \mathrm{k}$ to $42 \mathrm{k}$ in Sindh. Valuing one DALY at the average national per capita income, these reductions in disease burden represent a gross return of up to I\$ $405 \mathrm{M}$ and I\$ $155 \mathrm{M}$ in Punjab and Sindh, respectively, based on a $\mathrm{GNI}_{\mathrm{PPP}}$ of I\$ 5110 capita $^{-1}$ in Pakistan (Fig. 6e, f). These gross returns would multiply if a monetary value of double or triple per capita income were used, as suggested by the WHO, and these data are presented alongside for comparison. In terms of cost per DALY saved, these range from I\$ 461 to I\$ 619 and I\$ 292 to I\$ 370 in Punjab and Sindh, respectively. As such, the cost per DALY saved is well below the average per capita income in Pakistan and therefore $\mathrm{Zn}$ fertilisation in Punjab and Sindh can be considered a cost-effective public health intervention by WHO standards (WHO 2001).

The cost per DALY saved increases slightly as Zn fertiliser-use increases. In Punjab, the BCR of $\mathrm{Zn}$ fertiliser-use therefore decreases from 11.1 to 8.3 when one DALY is valued at the average national per capita income (Fig. 6g). The equivalent figures for Sindh show a decrease from 17.5 to 13.8 (Fig. 6h). This decrease is due to the use of the Estimated Average Requirement
(EAR) cut-point method to define the proportion of the population that is at risk of dietary $\mathrm{Zn}$ deficiency (Kumssa et al. 2015b). Because a normal distribution of $\mathrm{Zn}$ intakes is assumed for the population, when the mean population intake is $>E A R$, an increasingly smaller proportion of the population is moved out of deficiency for each projected incremental increase in $\mathrm{Zn}$ intake. In addition to increasing dietary $\mathrm{Zn}$ supply, the annual increase in grain supply would represent $19 \mathrm{~kg}$ capita $^{-1}$ across Punjab and Sindh which would improve general food security in terms of energy supply. This additional potential benefit is not factored into the current analysis.

\section{Discussion}

Our analysis shows there are likely to be substantial financial returns from an increase in $\mathrm{Zn}$ fertiliser-use in Pakistan, in terms of both yield and public health benefits. Our analysis is likely to underestimate these returns, based on the input data used, for several reasons. First, the current extent of dietary Zn deficiency in Pakistan is likely to be much greater than our assumed baseline of $23.9 \%$ according to the 2011 Pakistan National Nutrition Survey Report (NNS 2011). Second, no account has been taken of residual benefits of $\mathrm{Zn}$ fertilisers on subsequent crop yields or grain $\mathrm{Zn}$ composition. However, residual effects are likely to provide benefits for several years for both wheat and other crops (NFDC 1998; Singh and Shivay 2013; Manzeke et al. 2014; Wang et al. 2015b). Third, foliar $\mathrm{Zn}$ applications could make up a larger proportion of future $\mathrm{Zn}$ fertiliser-use, especially if it is applied in conjunction with pesticide sprays to minimise additional costs of application (Wang et al. 2015a; Ram et al. 2016). Fourth, if other hostile soil factors, such as B deficiency or salinity/sodicity, are addressed through soil management practices to improve yields, then greater returns per unit input of $\mathrm{Zn}$ are possible (NFDC 1998). Fifth, with yield increases, there is likely to be greater food consumption per se which is not accounted for in this study, although yield increases are likely to be minimal under foliar applications of $\mathrm{Zn}$ fertilisers (Joy et al. 2015b). Of course, if there is an increased supply of wheat, then this could reduce prices, and therefore reduce farmers' financial return from higher yields. However, greater yields would also likely increase the consumption of wheat both directly and indirectly via 
livestock. Thus both $\mathrm{Zn}$ and energy intake would likely increase, especially of low-income consumers, and therefore improve national food security. Given the commodity status of wheat and Pakistan's integration into global markets, an increase in wheat yields is not expected to have an impact on local prices.

To our knowledge, this is the first study that has combined both yield and health-based valuations to quantify the benefits of an increased projected supply of micronutrients through fertilisers. The potential BCRs relating to reductions in DALYs lost each year based on valuing DALYs conservatively at the national per capita income - are similar in scale to BCRs based on increased yield outputs based on increased $\mathrm{Zn}$ fertiliser-use. However, if multiples of the per capita income are used to estimate BCRs for reducing the number of DALYs lost each year, then the potential public health benefits of projected increases in $\mathrm{Zn}$ fertiliser-use far exceed returns that result from increased yields.

Such estimates of BCRs have profound implications regarding the question 'who pays?' for such a programme. There is clearly scope for farmers to pay for Zn fertilisers based on yield-related BCRs. However, this requires trust in the quality of fertilisers, access to fertilisers, commodity markets and credit, and adequate extension services. Asking consumers to pay a premium for wheat grain with increased concentrations of $\mathrm{Zn}$ is perhaps more challenging. A recent survey on the potential of iodine biofortification strategies in Uganda showed that despite some awareness among parents and school authorities of the essential role of adequate iodine for health, and salt iodisation programmes, there was little awareness of the potential role iodine biofortified foods could play (De Steur et al. 2015). However, consumers' willingness-to-pay for iodine biofortified vegetables is likely to increase in parallel with awareness of their potential health benefits (Mogendi et al. 2015).

Given the potential impact of $\mathrm{Zn}$ fertilisers on public health at the macroeconomic scale, including reduced health care costs and improved productivity, there seems to be a strong case for governments to consider subsidy programmes for $\mathrm{Zn}$ fertilisers. Furthermore, there may be additional micronutrient deficiencies that could be addressed through agronomic approaches, e.g. as discussed by Chilimba et al. (2012) and Joy et al. (2015a) for Malawi. In such cases government interventions could help overcome the lack of incentive that farmers have to pay higher prices for fertilisers that are also enriched with selenium or iodine, given that these minerals lack yield benefits. Agronomic approaches to deliver micronutrients also have the potential to reach wider sections of the community, including those who are socially excluded from fortification programmes which are delivered in schools or other community settings, for example, children with disabilities (Kuper et al. 2015).

While our framework to value fertiliser-based approaches to alleviating dietary mineral deficiencies provides a strong initial argument for pursuing such approaches further, based on economic and costeffectiveness considerations, we acknowledge that attention should be paid to ensure that: (1) the increased $\mathrm{Zn}$ supply through cereals is sufficiently bioavailable to have a dietary impact (e.g. Fredlund et al. 2006); (2) EARs are not over-estimated for the target population; (3) toxicity risks can be excluded; (4) the increased $\mathrm{Zn}$ supply does not exacerbate other micronutrient deficiencies or diseases; (5) decision-makers evaluate available options to improve public health and nutrition on a caseby-case basis to optimise the policy mix both in terms of targeting and budgetary considerations; (6) sufficient attention is paid to generate and use accurate baseline data, at sufficiently high geospatial resolution, of the nutritional composition of soils, crops and food, and of the nutritional needs of people.

Given the prevalence of dietary Zn deficiency globally, its alleviation falls clearly under the second of the United Nation's Sustainable Development Goals (UN 2015), which calls for an end to hunger, including access to sufficiently nutritious food by 2030 . We hope that this case-study provides a useful quantitative framework for assessing the potential impact of increased $\mathrm{Zn}$ supply in food systems from agronomic and breeding approaches to increase the $\mathrm{Zn}$ composition of food crops.

Acknowledgments This work was part-funded by a project of the Food and Agriculture Organization of the United Nations (FAO; Project Reference, GCP/PAK/130/USA, "Soil Fertility Management for Sustainable Intensification in Pakistan: Baseline Input Atlas and Promotion of Soil Fertility with Private Sector"). This project provided salary for WA and short-term consulting fees for MRB, as part of wider project activities. WA acknowledges the support provided by the Provincial Agriculture Extension Departments of Punjab and Sindh, for conducting the rapid fertilizer use assessment/survey. ELA and MJW are funded by the British Geological Survey, part of the UK Natural Environment Research Council (NERC). All views are the authors' own, and do not represent the views of the FAO or any other body. No other 
funding from public or private sources was received to undertake or report this study.

Open Access This article is distributed under the terms of the Creative Commons Attribution 4.0 International License (http:// creativecommons.org/licenses/by/4.0/), which permits unrestricted use, distribution, and reproduction in any medium, provided you give appropriate credit to the original author(s) and the source, provide a link to the Creative Commons license, and indicate if changes were made.

\section{References}

Ahmad N, Muhammad T (1998) Fertiliser plant nutrient management, and self-reliance in agriculture. The Pakistan Development Review 37:217-233

Ahmad W, Watts MJ, Imtiaz M, Ahmed I, Zia MH (2012) Zinc deficiency in soils, crops and humans: a review. Agrochimica 56:65-97

Alloway BJ (2008) Zinc in soils and crop nutrition, 2nd edn. International Zinc Association and International Fertilizer Industry Association, Brussels

Broadley MR, White PJ, Hammond JP, Zelko I, Lux A (2007) Zinc in plants. New Phytol 173:677-702. doi:10.1111/j. 1469-8137.2007.01996.x

Cakmak I (2008) Enrichment of cereal grains with zinc: agronomic or genetic biofortification? Plant Soil 302:1-17. doi:10. 1007/s11104-007-9466-3

Cakmak I (2009) Enrichment of fertilizers with zinc: an excellent investment for humanity and crop production in India. J Trace Elem Med Biol 23:281-289. doi:10.1016/j.jtemb. 2009.05.002

Cakmak I, Kalayci M, Ekiz H, Braun HJ, Kilinç Y, Yilmaz A (1999) Zinc deficiency as a practical problem in plant and human nutrition in Turkey: a NATO-science for stability project. Field Crop Res 60:175-188. doi:10.1016/S03784290(98)00139-7

Cakmak I, Kalayci M, Kaya Y, Torun AA, Aydin N, Wang Y, Arisoy Z, Erdem H, Yazici A, Gokmen O, Ozturk L, Horst WJ (2010) Biofortification and localization of zinc in wheat grain. J Agric Food Chem 58:9092-9102. doi:10.1021/ jf101197h

Chilimba ADC, Young SD, Black CR, Meacham MC, Lammel J, Broadley MR (2012) Agronomic biofortification of maize with selenium (Se) in Malawi. Field Crops Res 125:118-128. doi:10.1016/j.fcr.2011.08.014

De Steur H, Mogendi JB, Wesana J, Makokha A, Gellynck X (2015) Stakeholder reactions toward iodine biofortified foods. An application of protection motivation theory. Appetite 92:295-302. doi:10.1016/j.appet.2015.05.038

Fiedler JL, Lividini K, Kabaghe G, Zulu R, Tehinse J, Bermudez OI, Jallier V, Guyondet C (2013) Assessing Zambia's industrial fortification options: getting beyond changes in prevalence and cost-effectiveness. Food Nutr Bull 34:501-519

Food and Agriculture Organization of the United Nations (FAO; 1973) Report of the FAO/UNDP regional seminar on reclamation and management of calcareous soils. FAO, Rome. Available online: http:/www.fao.org/docrep/x5868e/ x5868e00.htm\#Contents [accessed April 2015]

Food and Agriculture Organization of the United Nations (FAO; 2015) FAOSTAT food balance sheets. Available online: http://www.faostat.org [accessed April 2015]

Fredlund K, Isaksson M, Rossander-Hulthén L, Almgren A, Sandberg AS (2006) Absorption of zinc and retention of calcium: dose-dependent inhibition by phytate. J Trace Elem Med Bio 20:49-57. doi:10.1016/j.jtemb.2006.01.003

Institute of Health Metrics and Evaluation (IHME; 2014) Global health data exchange, country-level global burden of disease data. Available online: http://ghdx.healthdata.org/ [accessed October 2015]

Joy EJM, Ander EL, Young SD, Black CR, Watts MJ, Chilimba ADC, Chilima B, Siyame EWP, Kalimbira AA, Hurst R, Fairweather-Tait SJ, Stein AJ, Gibson RS, White PJ, Broadley MR (2014) Dietary mineral supplies in Africa. Physiol Plant 151:208-229. doi:10.1111/ppl.12144

Joy EJM, Kumssa DB, Broadley MR, Watts MJ, Young SD, Chilimba ADC, Ander EL (2015a) Dietary mineral supplies in Malawi: spatial and socioeconomic assessment. BMC Nutr 1:42. doi:10.1186/s40795-015-0036-4

Joy EJM, Stein AJ, Young SD, Ander EL, Watts MJ, Broadley MR (2015b) Zinc-enriched fertilisers as a potential public health intervention in Africa. Plant Soil 389:1-24. doi:10. 1007/s11104-015-2430-8

Khan HGA, Ahmad A, Siraj A (2010) Impact of rising prices of fertilizers on crops production in Pakistan. Global J Manag Bus Res 10:54-61

Kumssa DB, Joy EJM, Ander EL, Watts MJ, Young SD, Rosanoff A, White PJ, Walker S, Broadley MR (2015a) Global magnesium $(\mathrm{Mg})$ supply in the food chain. Crop Pasture Sci 66: 1278-1289. doi:10.1071/CP15096

Kumssa DB, Joy EJM, Ander EL, Watts MJ, Young SD, Walker S, Broadley MR (2015b) Dietary calcium and zinc deficiency risks are decreasing but remain prevalent. Sci Rep 5:10974. doi:10.1038/srep10974

Kuper H, Nyapera V, Evans J, Munyendo D, Zuurmond M, Frison S, Mwenda V, Otieno D, Kisia J (2015) Malnutrition and childhood disability in Turkana, Kenya: results from a casecontrol study. PLoS One 10:e0144926. doi:10.1371/journal. pone. 0144926

Lim SS, Vos T, Flaxman AD, et al. (2012) A comparative risk assessment of burden of disease and injury attributable to 67 risk factors and risk factor clusters in 21 regions, 1990-2010: a systematic analysis for the global burden of disease study 2010. Lancet 380:2224-2260. doi:10.1016/S0140-6736(12) 61766-8

Manzeke GM, Mtambanengwe F, Nezomba H, Mapfumo P (2014) Zinc fertilization influence on maize productivity and grain nutritional quality under integrated soil fertility management in Zimbabwe. Field Crops Res 166:128-136. doi:10.1016/j.fcr.2014.05.019

Mogendi JB, De Steur H, Gellynck X, Makokha A (2015) Modelling protection behaviour towards micronutrient deficiencies: case of iodine biofortified vegetable legumes as health intervention for school-going children. Nutr Res Pract 9:e76. doi:10.4162/nrp.2015.9.e76 
Murray CJ (1994) Quantifying the burden of disease: the technical basis for disability-adjusted life years. Bull World Health Organ 72:429-445

National Fertilizer Development Centre (NFDC; 1998) Micronutrients in Agriculture: Pakistan Perspective. NFDC Publication No. 4/98 Status Report. NFDC, Islamabad, Pakistan.

National Fertilizer Development Centre (NFDC; 2013) Fertilizer Review 2012-13. Review Report 2/2013. NFDC, Islamabad, Pakistan

National Nutrition Survey (NNS; (2011) National nutrition survey of Pakistan. Aga Khan University, Pakistan and Pakistan Medical Research Council. Available online: https://www. humanitarianresponse.info/system/files/documents/files/59 National\%20Nutrition\%20Survey-2011.pdf [accessed April 2015]

Nayyar VK, Arora CL, Kataki PK (2001) The rice-wheat cropping system of South Asia: efficient production management. J Crop Product 4:87-131. doi:10.1300/J144v04n01 03

Pakistan Bureau of Statistics (PBS; 2009) Crops area and production by districts, $1981-82$ to 2008-09, volume I, food and cash crops. Government of Pakistan. Available online: http:// www.pbs.gov.pk/content/crops-area-and-productiondistricts-1981-82-2008-09 [accessed April 2015]

Pakistan Bureau of Statistics (PBS; 2010) Pakistan agricultural census 2010. Government of Pakistan. Available online: http://www.pbs.gov.pk/content/agricultural-census-2010pakistan-report [accessed April 2015]

Population Census Organization (PCO; 1998) Population and housing census 1998. Government of Pakistan. Available online: http://www.pbs.gov.pk/content/demographicindicators-1998-census [accessed April 2015]

Ram H, Rashid A, Zhang W, Duarte AP, Phattarakul N, Simunji S, Kalayci M, Freitas R, Rerkasem B, Bal RS, Mahmood K, Savasli E, Lungu O, Wang ZH, de Barros VLNP, Malik SS, Arisoy RZ, Guo JX, Sohu VS, Zou CQ, Cakmak I (2016) Biofortification of wheat, rice and common bean by applying foliar zinc fertilizer along with pesticides in seven countries. Plant Soil. doi:10.1007/s11104-016-2815-3

Singh A, Shivay YS (2013) Residual effect of summer green manure crops and $\mathrm{Zn}$ fertilization on quality and $\mathrm{Zn}$ concentration of durum wheat (Triticum durum Desf.) under a basmati rice-Durum wheat cropping system. Biol Agric Hortic 29:271-287. doi:10.1080/01448765.2013.832381

Stein AJ (2014) Rethinking the measurement of undernutrition in a broader health context: should we look at possible causes or actual effects? Glob Food Sec 3:193-199. doi:10.1016/j.gfs. 2014.09.003

Stein AJ, Meenakshi JV, Qaim M, Nestel P, Sachdev HPS, Bhutta ZA (2005) Analyzing the health benefits of biofortified staple crops by means of the Disability-Adjusted Life Years approach: a handbook focusing on iron, zinc and vitamin A. HarvestPlus Technical Monograph 4, International Food Policy Research Institute, Washington DC, USA, and International Center for Tropical Agriculture, Cali, Colombia
Stein AJ, Nestel P, Meenakshi JV, Qaim M, Sachdev HPS, Bhutta ZA (2006) Plant breeding to control zinc deficiency in India: how cost-effective is biofortification? Public Health Nutr 10: 492-501. doi:10.1017/S1368980007223857

United Nations (UN; 2015) Transforming our world: the 2030 Agenda for Sustainable Development. A/RES/70/1. Resolution adopted by the General Assembly on 25 September 2015. New York: United Nations. Available online: http://www.un.org/en/ga/search/view_doc.asp?symbol= A/RES/70/1 [accessed February 2016]

United Nations Population Division (UNDP; 2013) World population prospects: the 2012 revision. Available online: http:// esa.un.org/unpd/wpp/Excel-Data/population.htm [accessed November 2013]

United States Department of Agriculture (USDA, 2013) National nutrient database for standard reference, release 26. Available online: http://www.ars.usda.gov/ba/bhnrc/ndl [accessed: 20 November 2013].

Wang ZM, Liu Q, Pan F, Yuan LX, Yin XB (2015a) Effects of increasing rates of zinc fertilization on phytic acid and phytic acid/zinc molar ratio in zinc bio-fortified wheat. Field Crop Res 184:58-64. doi:10.1016/j.fcr.2015.09.007

Wang X-Z, Liu DY, Zhang W, Wang C-J, Cakmak I, Zou C-Q (2015b) An effective strategy to improve grain zinc concentration of winter wheat, aphids prevention and farmers' income. Field Crop Res 184:74-79. doi: 10.1016/j.fcr.2015.08.015

Wessells KR, Brown KH (2012) Estimating the global prevalence of zinc deficiency: results based on zinc availability in national food supplies and the prevalence of stunting. PLoS One 7:e50568. doi:10.1371/journal.pone.0050568

White PJ, Broadley MR (2009) Biofortification of crops with seven mineral elements often lacking in human diets-iron, zinc, copper, calcium, magnesium, selenium and iodine. New Phytol 182:49-84. doi:10.1111/j.1469-8137.2008.02738.x

White PJ, Broadley MR (2011) Physiological limits to zinc biofortification of edible crops. Front Plant Sci 2:80. doi:10. 3389/fpls.2011.00080

World Health Organization of the United Nations (WHO; 2001) Macroeconomics and Health: Investing in Health for Economic Development. Report of the Commission on Macroeconomics and Health. World Health Organization, Geneva. Available online: http://www.who.int/iris/handle/ 10665/42463 (Executive Summary), http://whqlibdoc.who. int/publications/2001/924154550x.pdf (Full PDF) p. 31, [accessed October 2015]

Zia MH, Watts MJ, Gardner A, Chenery SR (2015) Iodine status of soils, grain crops and irrigation waters in Pakistan. Environ Earth Sci 73:7995-8008. doi:10.1007/s12665-014-3952-8

Zou CQ, Zhang YQ, Rashid A, Ram H, Savasli E, Arisoy RZ, Ortiz-Monasterio I, Simunji S, Wang ZH, Sohu V, Hassan M, Kaya Y, Onder O, Lungu O, Yaqub Mujahid M, Joshi AK, Zelenskiy Y, Zhang FS, Cakmak I (2012) Biofortification of wheat with zinc through zinc fertilization in seven countries. Plant Soil 361:119-130. doi:10.1007/s11104-012-1369-2 